\title{
The symbolic meaning of Lulo dance: Tolaki tribe culture as communication medium
}

\section{Makna simbolik tari Lulo: Budaya suku Tolaki sebagai media komunikasi}

\author{
Mega Alma Narwasty*, Pamerdi Giri Wiloso, \& Gatot Sasongko \\ Masters of Development Studies, Faculty of Interdisciplinary, \\ Universitas Kristen Satya Wacana \\ Address: Jalan Diponegoro 52-60, Sidorejo, Salatiga, Central Java, Indonesia 50711 \\ E-mail: 092017011@student.uksw.edu
}

Article History: Received 24 April 2020; Accepted 14 March 2021; Published Online 19 April 2021

\begin{abstract}
Indonesia consists of various ethnic groups; the traditions and culture of each are different and have meaning. One of them is the Lulo dance from Southeast Sulawesi, which provides meaning and benefits to its supporters. This study aims to describe the Lulo dance movements' meaning in the culture of the Tolaki tribe and its use as a traditional communication medium in maintaining harmonious and peaceful relations amid Indonesian society's situations with so many different. This research used qualitative methods with descriptive analysis. The symbols of dance movements are analyzed with Barthes's semiotic theory through two stages of signification to get Lulo dance's meaning. Based on this study's results, the symbolic messages conveyed in this dance have a meaning that identifies unity, harmony, and mutual respect for differences. The message is packed with movements displayed in dance performance: the hands hold each other, the movements of the hands and feet, and the formation in a circle. Lulo dance, which is also called social dance, can be followed by everyone without exception. Therefore, this dance can strengthen the relationships between every human being. The Lulo dance performance is one of Southeast Sulawesi traditions used to achieve a harmonious and peaceful social life.
\end{abstract}

Keywords: communication medium; culture; Lulo dance; semiotic; symbolic meaning

\section{Abstrak}

Indonesia terdiri dari beragam suku; tradisi dan budaya masing-masing berbeda dan memiliki makna. Salah satunya adalah tari Lulo dari Sulawesi Tenggara yang memberikan makna dan manfaat bagi pendukungnya. Penelitian ini bertujuan untuk mendeskripsikan makna gerakan-gerakan tari Lulo pada budaya suku Tolaki dan pemanfaatannya sebagai media komunikasi tradisional dalam menjaga hubungan yang rukun dan damai di tengah situasi masyarakat Indonesia yang beragam. Metode penelitian ialah metode kualitatif dengan analisis deksriptif. Simbol-simbol gerakan tarian dianalisa dengan teori semiotika Barthes melalui dua tahap pemaknaan untuk mendapatkan makna yang terkandung dalam tari Lulo. Berdasarkan hasil penelitian, pesan-pesan simbolik yang disampaikan dalam tarian ini memiliki makna berupa identitas sebuah persatuan, kerukunan, serta saling menghargai perbedaan. Pesan dikemas dengan gerakan-gerakan yang ditampilkan dalam pertunjukan tarian, yakni posisi tangan yang saling berpegangan, gerakan tangan dan kaki, serta formasi membentuk lingkaran. Tari Lulo yang juga disebut sebagai tari pergaulan ini dapat diikuti oleh setiap orang tanpa terkecuali. Oleh karena itu, tarian ini dapat menjadi sarana dalam mempererat hubungan antar setiap manusia. Pertunjukan tari Lulo menjadi salah satu dari sekian banyak tradisi di Sulawesi Tenggara yang digunakan untuk mencapai kehidupan bermasyarakat yang rukun dan damai.

Kata kunci: media komunikasi; budaya; tari Lulo; semiotika; makna simbolik

\section{Introduction}

Indonesia consists of various ethnic groups; the traditions and culture of each tribe are also different. In Southeast Sulawesi, there are many different ethnic groups, both native and immigrant, ranging starting from Tolaki tribe, which is the majority, Bugis, Butonese, Muna, and Toraja. The Tolaki tribe has traditions and culture, including several arts, just like other tribes in Indonesia, ranging from fine arts, instrumental arts, literary arts, and traditional dance. One of the dances in the Tolaki tribal culture is the Lulo dance. The Lulo dance emerged in the traditional kingdoms and still exists and remains preserved until this day. In 2014, the Ministry of Education and Culture of Republic Indonesia in Putra (2018) established the Lulo dance, an essential symbol of the Tolaki tribe's life, as an intangible cultural 
heritage. As a cultural performance, the Lulo dance becomes an exciting dance for the Tolaki tribe and other tribes living in this provincial area. This dance is often presented as cultural performances at official events such as weddings, commemorating national days, and government activities. This dance is used as an entertaining performance in informal events like family gatherings or with work colleagues. Lulo dance is also called a social dance because it is often used to familiarize oneself. According to Melamba et al. (2015), Lulo dance is also created as a category in cultural competitions often held.

As a multicultural society, we will most likely communicate with people from diverse backgrounds, such as different ethnic, cultural, religious, or different languages. With these differences, people need to be aware and use communication to harmonize relations between others to create a sense of security and comfort. Culture, for example, is often used as a medium of communication to share messages about social values and norms prevailing in the society. Besides, it is from the community itself that the traditions or culture consider efficient because they have been passed down through generations and continue to be maintained. Therefore, the researcher tries to determine how far cultures can be used as a medium of communication in social life through several previous related studies.

The first previous study was the research that analyzes the symbolic meaning of the kejei dance, a Rejang ethnic group (Apindis et al. 2018). Apindis et al. (2018) used the perspective of symbolic interaction to interpret each element and movement of the kejei dance as a form of communication, and the results obtained that kejei dance has the meaning of gratitude to the creator and the ancestors for the abundant sustenance and harmonious life between them. The kejei dance is also by the Rejang community to facilitate getting a mate (Apindis et al. 2018). The second study researched symbolic interaction as a research approach and hermeneutical theory as an analysis theory (Imawan 2013). Imawan's (2013) results are that the bedaya kajongan dance has symbols of sacred values based on its history. The symbolic message lies in the overall dance movement that features war scenes, wherein this is intended for every woman to conquer her desires (Imawan 2013). Other research is on the Ma'atenu ritual, the Muslim community's rituals in Pelauw Village, Maluku Province (Sulaeman et al. 2019). Sulaeman et al. (2019) used an ethnographic communication approach based on symbolic interactions' perspective to observe the communication patterns and interactions in rituals. It was found that all ritual activities in Ma'atenu have the meaning of desire to serve, struggle, reduce bad attitudes, gain strength and immunity, and recover (Sulaeman et al. 2019). These things are displayed through specific symbolic behavior in the Ma'atenu ritual communication conducted by the Pelauw community (Sulaeman et al. 2019). Based on the previous study, the researchers used reference literature because there are similarities between those studies. The equation is in the research objects: cultural symbolic meaning used as a medium of communication, dance and ritual, and the research approach and symbolic interaction.

Nevertheless, the difference between this research and those previous studies is researchers' theory to analyze symbols. In those previous studies, there are deficiencies in the theory used as an analytical tool. Previous researchers used hermeneutic theory and subjective interpretation while this study analyzes symbols using semiotic analysis involving denotative and connotative meanings and mythological to see the meaning of the symbol, which is then observed with the symbolic interaction approach. In addition, the difference between the types of culture and research location also makes the analysis process different, and it also provides different results from previous studies. There is an interactive process between dancers to other dancers or dancers to the dance audiences, especially in dance. The interaction that occurs is a form of communication where, in most dance performances, the communication process is non-verbal communication. Non-verbal communication can be conveyed through symbols in body gestures, dancing movements, or facial conversions when serving dances.

Verbal and non-verbal communication can be distinguished based on the delivery process. Verbal communication uses words to convey messages, intentions, or information both verbally and in writing. Whereas non-verbal communication is all forms of communication carried out without using words (Kusumawati 2016, Rahayuni 2016). Hardjana (2003) defines non-verbal communication as a communication process in which the message can be conveyed using facial expressions, body gestures, 
movements, eye contact, and other symbols. The communication process, both verbal and non-verbal, following Lasswell's communication theory (Effendy 2011, Kholil et al. 2017), consists of the same components and elements, that is, sources, messages, media, receivers, and their effects (feedback).

With the presence of all these components, a communication process can then be said to be effective. Rakhmat (1996) mentions six types of non-verbal messages are often used, kinesics or gestures, proxemics or use of the room, artifactual, paralinguistic or sound, skin sensitivity or touch messages, and olfaction or smell. The existence of non-verbal communication activities involves the exchange of symbols as a communication message so that it is referred to as symbolic interaction.

Mulyana (2013) revealed several assumptions of symbolic interaction perspectives: 1) individuals respond to symbolic situations, it means a person can analyze the symbols that exist in the situation, and analysis process is carried out based on internal factors within each individual, 2) the result of social interaction, meaning in the process of interpretation is obtained and agreed upon through the use of language and in social interactions that occur, each individual can give meaning to everything in the form of objects, human behavior, events, and abstract things, 3) flexible; it can be modified and changed according to the situation in social interaction. The study's symbolic interaction approach prioritizes human behavior and action that the formation of meaning can influence. Meaning can not be interpreted until finally going through interpretation and is constructed by each individual in the interaction to produce a meaning that can be mutually agreed upon. Therefore, the symbolic interaction approach cannot be separated from the communication process. In line with that, Blumer's assumptions in Tamunu et al. (2018) regarding symbolic interactions are as follows: 1) humans act toward other people based on the meanings given by others to them, 2) meanings are created in human interactions, and 3) meanings are modified through interpretive processes.

The communication process with symbolic interactions that occur in it involves symbols that are interpreted as a sign. In his semiology study, Pierce distinguished signs into three types: icon, index, and symbol (Sobur 2013). This difference is based on the object and its representation. Equations and similarities mark icons, and the process of working is enough to see. Examples of icons are pictures, photographs, and sculptures. A causal relationship and interrelation characterize the index, the work process is estimated. Examples of indexes are smoke-fire and disease-symptoms. Furthermore, symbols are marked by conventions or social agreements, and the work process is to be studied. Examples of symbols are language, signaling, and movements (Wibowo 2011).

Humans will face signs whereby the meaning needs to be interpreted as to what is behind the signs with the interaction that occurs. Therefore, to examine and analyze the meaning of dance movements, which are symbols in a symbolic interaction situation, the researchers used a semiotic analysis by Barthes in Kusuma and Nurhayati (2017) which three main things are the core of the analysis: 1) denotative meaning system, which is the first level of meaning; it is also referred to as conceptual meaning or true meaning, 2) connotative meaning or the second level of meaning contain in an additional meaning called figurative meaning for examples, denotative meanings are on "roses" are flowers with red petals and thorny stems from the connotative meaning contained in roses as a symbol of romanticism. 3) myth was born and developed in society because of the influence of culture and social norms maintained in the community, and it can be interpreted by looking at the correlation between denotative signs, tangible signs, connotative signs, or implied signs.

Departing from the context of Saussure's semiotic thought, Barthes then developed the concept of Saussure's semiology, which only reached denotative meaning to connotative levels based on mythology or myth (Sobur 2013). According to Barthes in Ida (2014), the meaning contained in a sign is inseparable from the influence of certain people who make their ideological values into values that seem natural. Thus, Barthes's mythological concept is subsequently involved in the second stage of significance, the observed signs' connotation significance. 


\begin{tabular}{|c|c|c|}
\hline 1. Signifier & 2. Signified & \\
\hline \multicolumn{2}{|c|}{ 3. Denotative sign } & \\
\hline \multicolumn{2}{|c|}{ 4. Connotative signifier } & 5. Connotative signified \\
\hline \multicolumn{3}{|c|}{ 6. Connotative sign } \\
\hline
\end{tabular}

Figure 1.

Map of Barthes signs

Source: Cobley \& Jansz (Sobur 2013)

In Barthes signs map in figure 1, the meaning of a sign is generated through the denotative and connotative stages. Denotative in Barthes' semiology is the first stage where the meaning resulted is a conceptual meaning or actual meaning. Denotative sign (3) is obtained through signifier (1) and signified (2). At the same time, the denotative sign is also a connotative signifier (4). After going through the denotative stage, the connotative stage is carried out, where this stage involves mythology or society belief as a connotative signified (5). Furthermore, the resulting connotative sign (6) is a figurative meaning which means it is indirect and has the possibility of new interpretations (Sobur 2013).

Traditional communication medium are most widely used to convey semiotic messages that contain values in society. These are communication medium in cultural arts or customs that emerge and develop amid society (Walujo 2011). Traditional communication medium are considered to have a unique attraction and can make it easier for people to communicate verbally and non-verbally about the values held by their people in their social life because they come from the people and are an inheritance that has been preserved since ancient times. In addition to empowering traditional values, traditional communication medium are often used for education and entertainment (Ngare 2014).

Culture in the form of rituals, dance performances, or others, can have a role as a communication medium that is used to spread information that contains the values and ideology of a particular society to the broader community, as the function of communication medium, in general, is to be a tool to convey messages to the public (Arifianto 2015). In the delivery through culture, symbolic representations occur where each individual's agreed meaning results from production and exchange (Ibrahim 2007). Martin and Nakayama in Istiyanto and Novianti (2018) explain the relationship between communication and culture that communication and culture are intertwined. Communication behavior in each individual is influenced by meaning analysis and interpretation of reality in a culture (Lagu 2016). Likewise, the cultural identity passed down from one person or group to another is formed from the background and communication process. Hall in Istiyanto and Novianti (2018) expressed culture and communication's attachment in saying, culture is communication and communication is culture. According to Hall in Istiyanto and Novianti (2018), preserving a culture so that it can be passed down from generation to generation is determined by one crucial factor: communication, while culture itself is an inseparable aspect of communication behavior.

This study aims to find the symbolic meaning of the Lulo dance movements, which use as a communication medium in conveying the values and ideology of community life. Explicitly, this research was conducted to determine the meaning of the Lulo dance movement and how Lulo dance as a Tolaki tribe tradition became one of the communication medium that can strengthen the relationship between the Tolaki and other tribes living in Southeast Sulawesi.

\section{Research Method}

The approach used as a methodological foundation in this research is a qualitative descriptive approach that aims to analyze and interpret culture in the text's form to be more easily understood. Researchers use this approach to help understand and analyze a symbolic message through descriptions and interpretations 
of the informants studied in depth. The the critical informants chosen were Tolaki Customary Institution or Lembaga Adat Tolaki (LAT) administrators, namely AAM, a cultural activist, and Tolaki traditional figure ASM. The two informants chosen are Tolakinese so that the researchers could obtain clear and complete data. AAM is a permanent lecturer at the Faculty of Cultural Sciences at one of the state universities in Kendari, Southeast Sulawesi, and to this day still contributes to the cultural studies of the Tolaki tribe. Simultaneously, besides serving as a Tolaki traditional figure, ASM also works as a civil servant in the Konawe District.

In this study, the research object is the symbolic meaning of the movements and the Lulo dance as the research subject. Data collection was done through participant observation, in-depth interviews, and document review (Moleong 2010). Meanwhile, the data analysis stage was carried out with steps according to Creswell. First was preparing and organizing data for analysis. This step involves interview transcripts, material scanning, sorting out field data, and organizing the data according to information sources. Second, read and explore accurate data. In this stage, they were writing a specific note or general idea about the data obtained. Third, analyze in more detail through coding data. Fourth, apply the coding process to describe the settings, people, categories, and themes to be analyzed. Fifth, restate the qualitative narrative or report. Sixth, interpret the data (Andung \& Nope 2017).

\section{Results and Discussion}

\section{The history of Lulo dance}

The Lulo dance comes from the word moLulowi, which means the activity of trampling, seeing the traces of its history. The word Lulo means to step on, and wi is used to affirming the work done, whereas the prefix mo means repetitive work. Thus, moLulowi means doing Lulo dance with trampling movements; AAM stated:

"In the past, after harvesting rice, people had to trample it using their feet to produce rice. It is the beginning of moLulowi activity. From moLulowi's activities, they express it in the form of dance. This Lulo dance appears as a thanksgiving to the goddess of rice for the abundance of crops, especially rice."

It is known that Lulo or moLulo dance emerged related to the Tolaki tribal activities in agriculture. In the past, to separate rice from its skin, the Tolaki people had to trample it with their feet. The public then expresses this activity in the form of a dance that is called the Lulo dance. Lulo dance is performed in a harvest celebration ritual called monahundau, a sacred ritual dedicated explicitly to the rice goddess called Sanggoleo Mbae. The ritual by presenting Lulo dance is a form of gratitude for the abundance of crops and respect for Sanggoleo Mbae. In some oral traditions, the activity of moLulo dance is thought to emerge when people are familiar with agricultural activities in the 9th century. Lulo dance used in agricultural rituals is also called Lulo Ngganda, which, besides being performed in thanksgiving rituals, is also used in new land clearing ceremonies for farming by holding hands and saying prayers to the gods. Lulo dance, which originated from agricultural activities in its development, is also used in ritual healing cures. The Tolaki tribe considers that the disease is caused by nature so that humans can be affected by the plague. Healing rituals contain prayers chanted to the God (Sangia) as a form of a request for healing. Therefore Lulo dance in this healing ritual is called Lulo Sangia.

Along with the times, Lulo dance is used in traditional rituals; however, it is more often used as a cultural identity of the Tolaki tribe, which is related to the diversity and harmony of the community, especially in Southeast Sulawesi. Lulo dance as cultural performance art is generally displayed in several events, such as weddings, traditional celebrations, cultural festivals, tourism activities, and even in competitions. In this case, Lulo dance has become a prevalent tradition and is often performed by the community, both by the Tolaki and other tribes in Southeast Sulawesi. The movements are easy to follow; the Lulo dance is popular because there are no age, class, or tribal restrictions in performing this dance. Like other 
dance arts, Lulo dance in its performances also includes certain aspects. Although the elements in this dance continue to evolve and change over time, the values contained therein are never removed. Some elements in dance are costumes, accompaniment music, dancers, and also formations and movements.

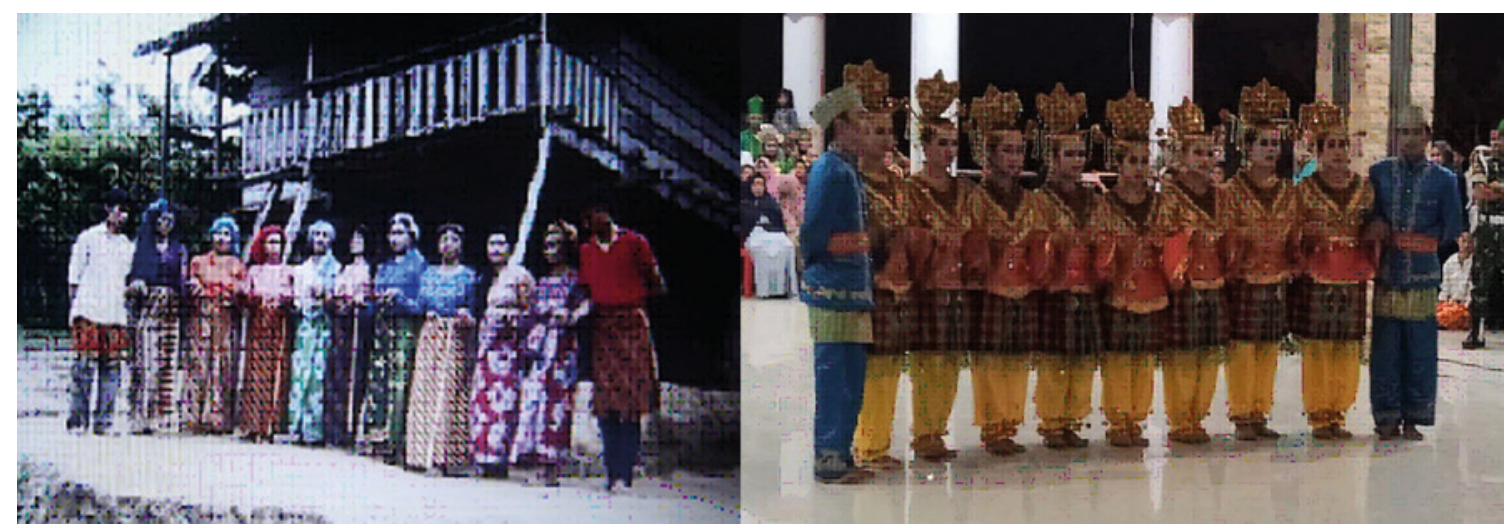

Figure 2.

Costum of dance participants in Lulo dance as ritual (left) and traditional, creation Lulo contest (right) Source: Alim (2015) \& personal documentation

\section{The Lulo dance costume and participants}

In the ritual implementation of Lulo dance, the type of clothes used is not bound. Tolaki people at that time used modest clothing worn on the body. Over time, Lulo dance is now better known by its tradition as a social dance in the performing arts. In their official appearance in the show, the dancers generally wear regular Tolaki clothes, where this costume deliberately shows the identity of the Tolaki tribe. In Lulo dance performance as a social dance informal events, male dancers wear long- sleeved tops, long pants with the sarong, and a headband called pasapu, while, for female dancers, the clothes used are long-sleeved tops without any slit, which are called babumbineboto, and their lower garment is a sarong that reaches their heel (Melamba et al. 2015), all are these the typical Tolaki tribe costumes (Figure 2). Meanwhile, in the mass Lulo dance, an entertainment event, people can wear clothes or costumes that are more free and diverse.

This dance can be followed by men and women and can be performed by all society levels together, both ordinary people and governments, Tolaki and other tribes, young or old, any kind of religion, race, or specific groups. Lulo dance or MoLulo in its context as a social dance, can be participated by an unlimited number of people because of its nature as a mass dance. Mass Lulo dance is usually held as a closing event, where all the people at the event. Including guests, government officials, and also the society who came along are allowed to follow the dance by forming a large circle with holding each other's hands.

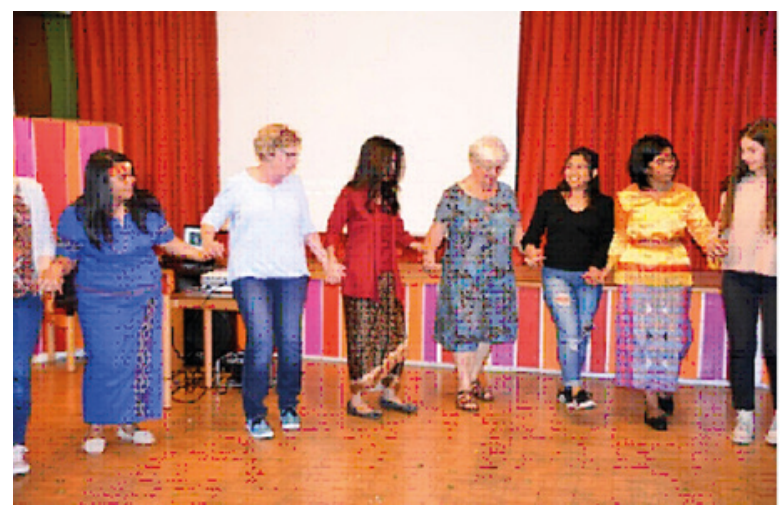

Figure 3.

Lulo dance in Indonesia-Germany Youthcamp (2018) Source: Personal documentation 
As in the figure 3 above, the Lulo dance is performed as a form of introduction from Indonesia participants. The Lulo dance participants use traditional clothes from different tribes to strengthen the message to be conveyed, to show Indonesia as a multicultural country that has various traditions and cultures. The culture differences are not the reasons to divide but instead strengthen the relationship between each community. Lulo dance is considered as the most representative tradition of the participants to provide an understanding of this.

\title{
Instruments of Lulo dance
}

The beginning of the Lulo dance was accompanied by the chanting of prayers by the Tolaki tribal community themselves. Afterwards, simple musical instruments began to be used to complete the dance. Kanda-kanda wuta and o kanda was the initial instrument that accompanied Lulo dance. These kandakanda wuta are made of soil, while o kanda is made from animal skins that resemble drums, and both are played by being hit (Figure 4). After that time, several simple musical instruments were used in the Lulo dance during the ritual ceremony, which are drums made from bamboo blades cut in such a way, drums made from animal skins, and gongs. The existence of gongs as dance accompaniment music is due to Islamic influence in the Konawe. AAM said:

\begin{abstract}
"As for accompaniment, in the old days, it was accompanied by singing from their mouth, and they also used simple tools as accompaniment. There is such thing called o kanda and kanda-kanda wuta, the initial instruments accompanying the Lulo dance. There are several types of musical instruments for the ritual process, which also transform along with the times. For the performing arts, musical instruments are used, ranging from gongs, drums, or music recorded and then played back. The accompanying music in the performing arts is more enjoyable. Different with the rhythm for ritual."
\end{abstract}

According to Alim (2015), Lulo dance accompaniment music is more varied as a cultural art performance. Various musical instruments are used, ranging from gongs, drums, electric pianos, commonly called electons, or music that has been recorded and then played back. Accompaniment music in the performing arts is more directed to rhythmically beautiful music and expresses joy, in contrast to the rhythm of music for Lulo dance in rituals in ancient times.

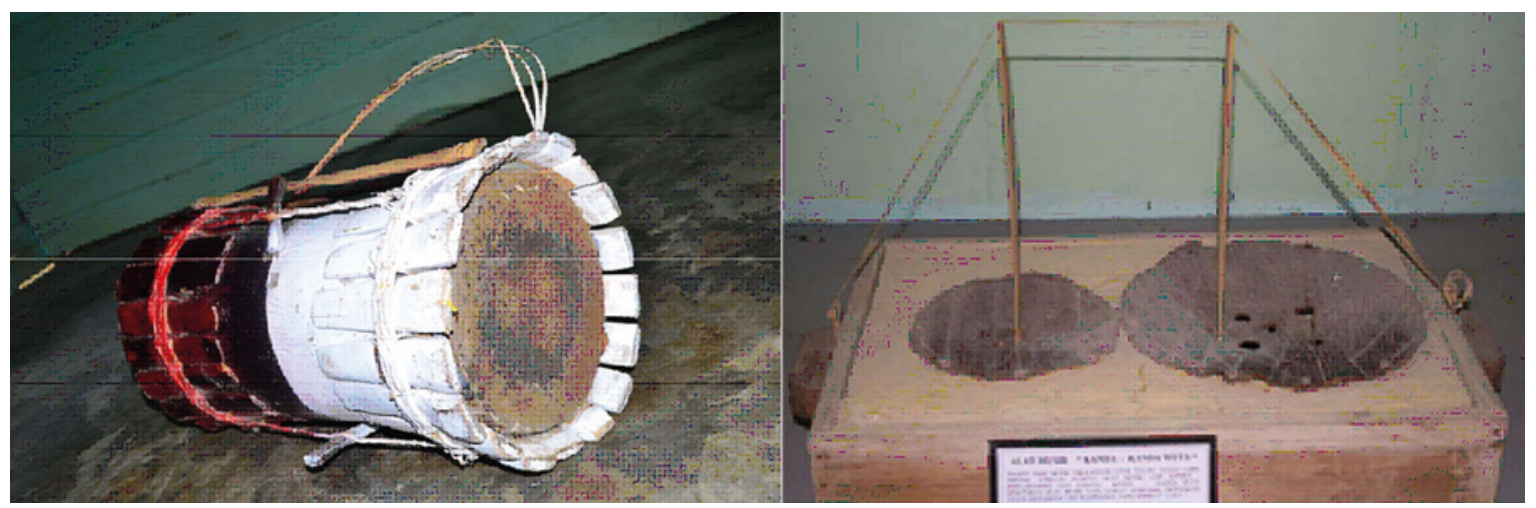

Figure 4.

O kanda (left) and kanda kanda wuta (right)

Source: Personal documentation

\section{Lulo dance movements}

Lulo dance performance, in its current implementation as performance art, has movements that are adapted from movements that had existed since ancient times when Lulo dance performed in traditional rituals. These have also been modified along with the times; the basic movements in Lulo dance, which contain Tolaki tribe values, are still maintained. These movements explain by ASM, a cultural activist and Tolaki traditional figure, stated: 
"Lulo dance performed in the tradition of agricultural rituals and healing as well as in the performing arts has movements that tend to be the same. The names of the movements are different in the Tolaki language; however they tend to be the same. Just because there are variations in leg movements and performed in different situations, the name is different. There is a movement called mekai-kai, moese, molako-ako, ndinuka-tuka, or sometimes called niLulo-Lulo."

ASM explained the meaning of the Lulo dance movements performed in art performances, he said:

\begin{abstract}
"Mekai-kai is a hand-holding gesture. In Monahundau as ritual tradition this gesture is also commonly called mekai-kai. It is the dancer's movements after entering from the front. They hold hands and form a circle. Moese is the dancer's hand movements that swung up and down while still holding hands. This position requires the woman's hand is above, and the man's hand is below. Molako-ako is a movement that moves leg to the left and right to the rhythm of the music. Then ndinuka-tuka or niLulo-Lulo movement means stomping on the ground or trampling."
\end{abstract}

Through an interview with ASM, the researchers found that the basic movements of the Lulo dance remained broadly the same, both in harvesting and healing rituals and in cultural performance. These movements have several different terms in the Tolaki language, depending on where and in what situations it is used. However, the hand and foot movements in the ritual are also performed in the performing arts with different names and terms. The movements performed in rituals and performed in the performing arts were the basic movements that existed long ago when the Lulo dance first appeared. The movements are hand moves up and down, the foot moves to the right and left, and trampling or stomping to the ground. The body gestures displayed are also identical, which are how dancers enter the dance line from the front, formation in a circle, and certain positions of the dancer's hands. There are more types and variations of Lulo dance that have been introduced to the public until now. This diversity caused by many factors, such as musical instruments, regional origin, and even the name of the creator; nevertheless, even though it consists of relatively many types, the basic principles of movement in this dance are still the same, forming a circle with hands moving up and down and feet stomping on the ground.

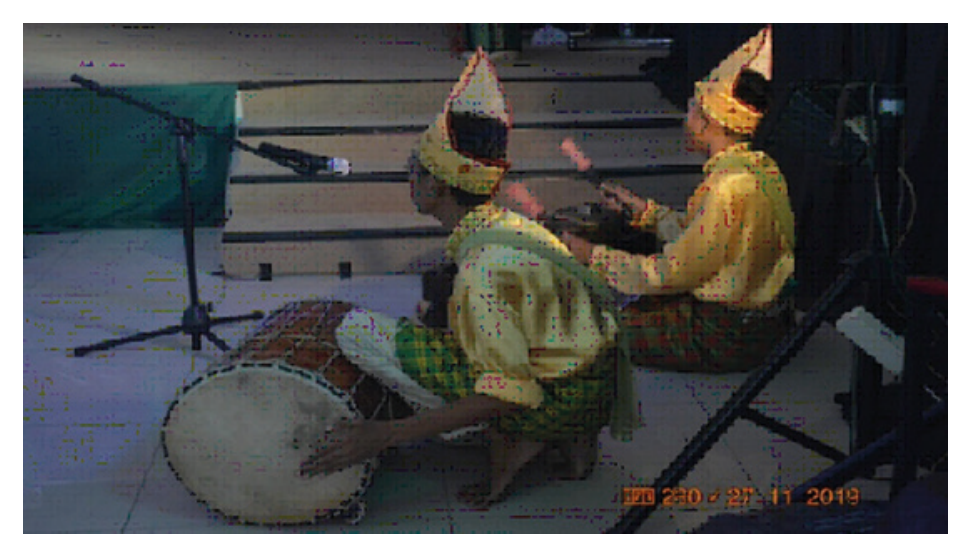

Figure 5.

Drum and gong as Lulo accompaniment in cultural arts performance (2019) Source: Personal documentation

One of the events that commonly performs Lulo dance in Southeast Sulawesi is the Cultural Art Performance, as seen in the figure 5 above. Lulo dance in this event is generally accompanied by drum and gong as the musical instruments. Apart from electone, drum and gong are the musical instruments that most used to accompany Lulo dances in the form of performing arts. The music player usually consists of two people, each for the drum and also the gong, as shown. The drum and gong are hit with a rather fast motion resulting in attractive and cheerful sounds. 


\section{Semiotics analysis in Lulo dance movement symbols}

Lulo dance, both in rituals and as an art performance, has the same basic movements. These movements are analyzed by Barthes's semiotic theory, which goes through two stages of significance, denotative and connotative stages. Following Barthes' sign map (Figure 1), denotative signs are obtained through the existing signifier and signified, which, in this process, the signifiers are mekai- kai, moese, molakoako, and ndinuka-nuka or niLulo-Lulo. In contrast, the signified is the term in the Tolaki language. The denotative sign that comes after is the meaning of the movement that has been translated. Furthermore, the denotative sign also becomes a connotative signifier and the myths in the Tolaki tribe as the signified. In this connotative stage, the meaning of the movement is based on the myths and beliefs of the people who existed long ago.

\section{Denotative stages}

Barthes' denotative sign in his sign map consists of a signifier and signified; however, at the same time, the denotative sign also becomes a connotative signifier. The denotative stage is the first level of the meaning system carried out before entering the second level of the meaning stage, which is the connotative stage. The first sign is mekai-kai in Tolaki and is the term for hand-holding movements performed by Lulo dance participants when they enter a dance line while forming a circle. The second sign is moese, meaning a hand movement in Lulo dance, which is a movement of raising the hand slightly upwards and then swinging it down and doing it repeatedly. This hand movement is done slowly and gently. The third sign is molako-ako, the foot movement by stepping left and right to the rhythm of the music. The fourth sign is ndinuka-tuka or niLulo-Lulo. This term in Tolaki is defined as stomping to the ground, left and right legs swung alternately quickly like jumping up and down. Based on the signs that interpreted through the stages of the denotation, it found that the basic movements of Lulo dance have not changed until now and are still carried out in their present context as performing arts. The denotation meaning obtained is that the position of men's hands must be under the women's hands, up and down hand movements, the movements of the feet moving right and left, the movements of stomping, and the formation in a circle.

\section{Connotative stages}

After going through the denotative stage, the researchers carried out the connotative meaning stage, where this stage involves mythology in the meaning process. Barthes in Wijaya and Marta (2015) explored by adding myths to his theory, and the myth contains beliefs and values that have been formed in the community. Myths and ideologies in Barthes' theory are the basis for analysis and describe the connotative meanings in the symbol as a sign on the Lulo dance. The presentation of Lulo dance was initially carried out in a ritual that was considered very sacred. The Tolaki tribe believes that the Lulo dance performed in a series of rituals can be their communication medium to convey requests and worship to their gods. Therefore, the movements that appear in the Lulo dance are also based on myths believed by the Tolaki tribe in the past.

Mekai-kai, or the hand-in-hand movements, first appeared when the Lulo dance was performed during a harvest celebration ritual. Dancers trampled rice to separate rice from their skin, and while holding hands, they assume that prayers that are sung together for Sanggoleo Mbae will be delivered because of everyone's cooperation. Even until the Lulo dance became an art performance in the healing rituals, this hand-in-hand movement remained and became the primary movement in the Lulo dance. The connotation meaning in this movement is a concept of togetherness, where it is shown when the dance starts with each person then everyone holding hands into one group. This movement reflects the traditional value of the Tolaki tribe, mepokoaso, which means unifying, as the gesture of holding hands aims to enable the Lulo dance to unite various ethnicities and cultures wherever this dance is presented. Moese, the movement of the hands swinging up and down while still holding hands with each other. The position of the woman's hand must be above the man's hand. In the healing ritual myth, the hand movements 
that are swung from top to bottom describe the sick's state and still lying weak. In this movement, the connotation meaning contained is the harmony of the community in moving together. It can be seen in the solidarity of the Tolaki tribe community, who empathizes for someone who is sick and then sends their prayers and requests to the Sangia. In Lulo dance as a cultural performance, this movement can be interpreted as a form of acceptance by not questioning differences in age groups and ethnicities. This hand in hand position requires a man's hand to be placed under a woman's hand as a form of protection for women, in the sense that female dancers lead hand movements.

In molako-ako, which is the foot's movement to left and right, the connotation meaning obtained is that a movement is a form of gratitude and excitement for the event that occurred or the situation. Previously, in healing rituals myth, this movement illustrates that sick people show changes, begin to wake up, and become healthy again. Furthermore, the movement of stomping to the ground that is ndinuka-tuka or niLulo-Lulo has a connotation meaning that it is a form of maintenance culture of the Tolaki tribe who have always carried out traditional rituals as a form of their thanksgiving for the abundance of the harvest. It relates to the belief of those who worship the Sanggoleo Mbae (rice goddess) when separating rice from its skin by stepping on it. Likewise, with the formation of a circle inseparable from the ancient Tolaki tribal community's values and ideology. The circle formation in the Lulo dance is identical to the kalosara as a symbol of Tolaki's customary law system in maintaining peace and unity (Figure 6). Kalosara is a circular rattan with both ends knotted and then placed on a square woven fabric. In the literal meaning, kalosara consists of two words: kalo means a rattan piece with three circular turns, and sara means rules and law symbols (Tarimana 1993).

In this study, the researchers obtained the meaning of the dance moves as a communication message through the analysis phase, so the results obtained are based on the theory used. The researchers observed the movements in Lulo dance as a symbol (sign) that must be interpreted through the stages of analysis to find the meaning contained in it. Therefore, the researchers analyzed the meaning of dance movements, which are symbols (signs), using Barthes' semiotics. The meaning of symbols obtained is then observed with the perspective of symbolic interaction. The symbolic interaction perspective is used to see the interactions or communication processes involving these symbols. According to Blumer in Tamunu et al. (2018), symbolic interaction is present in people's lives because of an interaction and communication process carried out by each person using symbols. The meaning in these symbols is following an agreement with the community (Apindis et al. 2018). When someone does the symbolic interaction, it means that the person uses symbols as their communication message. Thus, the symbolic interaction is a communication process called non-verbal communication, where the characteristic of non-verbal communication is not using words; however, symbols as a substitute. These symbols can be expressions, movements, and body language.

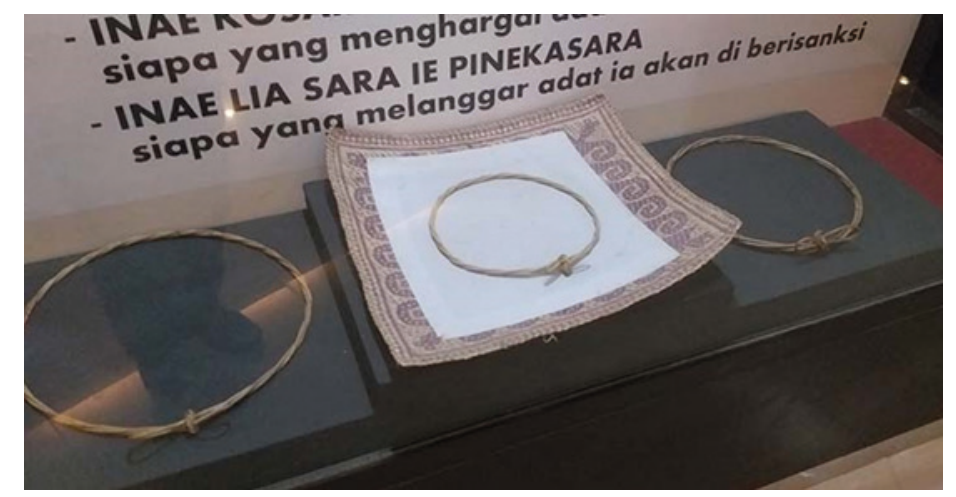

Figure 6.

Kalosara symbol in Southeast Sulawesi Provincial Museum Source: Dalma (2019)

The symbolic interaction perspective helps researchers thoroughly observe the symbols used in Lulo dance as the traditional communication medium. After conducting a semiotic analysis process, the 
researchers found that the symbols in the Lulo dance declared the identity of unity and harmony as outlined in the movements displayed, which are the position of the hands holding each other, specific movements on the hands and feet, and formations forming a circle. The meanings in these movements are then exchanged through symbolic interactions that occur when the dance process takes place. Based on Blumer's in Tamunu et al. (2018) symbolic interaction assumptions, the researcher obtained a description of the meaning carried out by individuals through symbolic interactions in the Lulo dance.

First, the meaning of the Lulo dance movements is intended as a message to provide awareness to the community, especially in the area where this dance presents, so that the actions created in the community are to maintain harmony in social life with others. Differences in each individual are expected not to influence the community's behavior to maintain unity as a plural society. Second is the meaning conveyed in the delivery process, given by Lulo dance participants to other dancers and the dance audiences. The meaning created comes from symbolic interactions that occur in dance performances and process through their respective interpretations following the teachings, experiences, and knowledge that recipients of the meaning have possessed. The third is that the Lulo dance movements' meaning is through an interpretative process and can be modified through such a process.

The researchers see the existence of non-verbal communication that occurs in Lulo dance performance, which involves dance participants as communicators (people who deliver messages) and other participants and dance audiences as communicants (people who receive messages), through Lulo dance as the communication medium. The message conveyed lies in the symbol of the dancer's basic dance movements, where each individual can interpret the meaning of the symbolic movement in the communication process. Several non-verbal messages are used in non-verbal communication through Lulo dance, first, kinesics or gestures; in presenting a dance, body movements are the main thing. The movements used in the Lulo dance and intended as a message are forming a circle and the basic Lulo dance movements, which are called mekai-kai, moese, molakoako, and ndinuka-tuka or niLulo-Lulo. Like the way dancers, certain gestures get to the line at the beginning of the dance, a circle formation, and hand positions holding each other. Second, proxemics or space using space between one dancer when doing the Lulo dance is very close to each other; this is marked by the elbow position of the participant dancers that generally touch each other. Third, touch messages, in which the Lulo dance tradition, the dancers' hands, and elbows' position are required to touch each other by holding the dancers' other hands on the left and right and close their elbows together.

Lulo dance tradition, in its function as a communication medium takes on the role of entertainment and empowers the Tolaki tribal traditional values. In the past, Lulo dance performed in sacred rituals and became a medium of communication for the Tolaki people in conveying their prayers to the gods for healing in the ritual treatment and thank the abundance of the harvest. With the socio-cultural development, Lulo dance continues to be preserved and has become a medium of communication in spreading Tolaki ethnic, cultural values to the broader community, especially in Southeast Sulawesi. Cultural arts performances featuring the Lulo dance are among the Tolaki people's efforts to maintain a harmonious and peaceful social life with the many other tribes living in Southeast Sulawesi. This harmonious social life is shown through certain aspects used as an indicator of community harmony. Some of these aspects include social relations, religious relationships, and social values owned by the local community.

Previous research found that the community harmony index in the two areas is at a high enough value even with a high plurality level. Abas and Haq (2016) revealed that openness in social interactions and mutual respect make social relationships between communities run well. This open attitude in interacting is inseparable from the religious and cultural values of each tribe living in the area, such as the Tolaki, Muna, and Buton. Saprillah (2016) found that even though in religious relations, sometimes there are still some religious groups that experience obstacles in celebrating their religious celebrations, which does not affect the quality of harmony and social relations between them. In addition, the research findings also show that acceptance and appreciation between each community are relatively high. One 
of the factors, among others, is the character and values of the Tolaki tribe in building social relations. These values want to continue to be shared through the traditions and culture of the Tolaki tribe, one of which is the Lulo dance. Remembering that the culture of Lulo dance has become a hereditary cultural heritage and originates from the community itself, the message and meaning in Lulo dance are expected to be more readily accepted by the community.

Compared to the kejei dance (Apindis et al. 2018), there is a similarity in this research in that the symbols are displayed through the dancers' body gestures and dance movements. The gesture referred to in the kejei dance is the position of separate male and female dancers, the position of female dancers sitting between the table offerings, the position of the dancer's head bowed, and also the movements, namely sembah menari, bederap salah, metik jari, mateak dayung, sembah penyudo, and mendayung. Similarly, in research on the culture of bedaya kajongan dance (Imawan 2013), the equation also lies in the symbols, the dance movements. The movements in bedaya kajongan dance are lelaku, ngayun, membawa gada, and goleng. In Lulo dance, the symbols are given also lie in the dance gestures and movements, which are the dancers' gestures entering dance lines, dancers' formation in a circle, and the basic movements of Lulo dance which, in Tolaki terms, are called moese, molakoako, and niLulo-Lulo. The difference between this research and the two other studies is the type or form of the movements and gestures displayed, so the meanings produced based on these symbols are finally different.

Meanwhile, the similarity in research on Ma'atenu rituals with this Lulo dance research (Sulaeman et al. 2019) is that the whole set of the culture's ritual and dance performance interpret as a process of communication. This communication process is equally displayed through symbolic behavior. The difference between the Ma' atenu ritual and Lulo dance is based on the results that lie in the communication component in the communication process: different sources, recipients, media (rituals and dances), and different messages. The novelty in this study is the different meaning produced by a culture in a society based on the results, where the meaning that exists in the Lulo dance tradition in the Tolaki tribe shows the cultural identity of the Tolaki tribe, which respects differences, uphold unity and always maintains harmony between the Tolaki people and other tribes in Southeast Sulawesi.

\section{Conclusion}

Lulo dance is a traditional dance of the Tolaki tribe that was once performed in traditional rituals. Along with the times, the tradition of Lulo dance is displayed in art performances to aim that this culture does not disappear and can continue to survive over time. In rituals and performing arts, this dance's traditional values remain the same and do not change. Lulo dance, in its movements as a symbol, contains meaning that is about mutual respect and prioritizes unity and harmony in living life. The symbolic meaning of the Lulo dance is inseparable from the series of myths and beliefs of the ancient Tolaki people so that the dance movements that exist today are a representation of the Tolaki tribe's traditional values that are still accepted and continued by the community until now; however, with various changes adjusted. This meaning display through movements called mekai-kai, moese, molako-ako, and ndinuka-tuka or niLulo-Lulo.

The Lulo dance is used as a communication medium to preserve the traditional values believed by the Tolaki tribe community to deliver the meaning of the movement symbols to everyone. In Lulo dance performance, there is an interaction or communication process involving the symbols of dance movements.This interaction is called non-verbal communication where, in the process, this symbolic interaction involves symbols as communication messages. The communication process occurs between the dance participants as the person delivering the message (source), other participants, and the dance audience as the person who receives the message (receiver) through the Lulo dance as a communication medium, and with the communication effect (feedback) expect to emerge being a harmonious life between the Tolaki and other tribes, respect of each other and accepting differences, and also constantly trying to maintain peace. Therefore, the Lulo dance is one of many traditions of the Tolaki tribe which expected to be passed down from generation to generation and its existence preserved, considering that 
it is an essential symbol of the Tolaki tribe's life and plays a role in maintaining the social life of the wider community, especially in Southeast Sulawesi through the social and cultural values presented in this dance.

\section{References}

Abas M \& Haq P (2016) Indeks kerukunan umat beragama di Kota Kendari ditinjau dari aspek hubungan sosial, hubungan keagamaan, nilai dan peran pemerintah. Jurnal Penelitian Pendidikan Sejarah 1 (1):1-11. http://dx.doi.org/10.36709/jpps.v1i1.7350.

Alim A (2015) Transformasi tari Lulo pada masyarakat Tolaki di Kabupaten Konawe, Sulawesi Tenggara. Dissertation, Universitas Udayana, Denpasar.

Andung PA \& Nope HA (2017) Media rakyat sebagai media komunikasi pembangunan masyarakat Suku Boti. Jurnal Ilmu Komunikasi 14 (2):277-292. https://doi.org/10.24002/jik.v14i2.870.

Apindis GAMC, Hanum SH, \& Hartati S (2018) Makna simbolik tari Kejei suku Rejang. Jurnal Sosiologi Nusantara 4 (2):64-75. https://doi.org/10.33369/jsn.4.2.64-75.

Arifianto S (2015) Use of traditional art as means of public information dissemination. IPTEK-KOM 17 (1):71-86.

Dalma MT (2019) Kalosara dari dulu hingga kini: Merawat perdamaian, mengokohkan persatuan. [Accessed 19 March 2020]. https://zonasultra.com/kalosara-dari-dulu-hingga-kini-merawatperdamaian-mengokohkan-persatuan-bagian-1.html.

Effendy OU (2011) Ilmu Komunikasi Teori dan Praktek. Bandung: Remaja Rosdakarya.

Hardjana AM (2003) Komunikasi Intrapersonal \& Komunikasi Interpersonal. Yogyakarta: Kanisius.

Ibrahim IS (2007) Budaya Populer sebagai Komunikasi: Dinamika Popscape dan Mediascape di Indonesia Kontemporer. Yogyakarta: Jalasutra.

Ida R (2014) Metode Penelitian Studi Media dan Kajian Budaya. Jakarta: Prenada Media Group.

Imawan K (2013) Pesan simbolik dalam seni tari Bedaya Kajongan sebagai realitas budaya masyarakat Cirebon. Signal 1 (2):1-11.

Istiyanto SB \& Novianti W (2018) Etnografi komunikasi komunitas yang kehilangan identitas sosial dan budaya di Kabupaten Cilacap. Jurnal Kajian Komunikasi 6 (1):64-77. https://doi.org/10.24198/ jkk.v6i1.15213.

Kholil S, Zulkarnaen I, Mauidhah CA (2017) Pesan-pesan komunikasi Islam dalam tarian tradisional Seudati Aceh (analisis semiotika). AT-BALAGH 1 (1):29-40.

Kusuma PKN \& Nurhayati IK (2017) Analisis semiotika Roland Barthes pada ritual Otonan di Bali. Jurnal Manajemen Komunikasi 1 (2):195-217. https://doi.org/10.24198/jmk.v1i2.10519.

Kusumawati TI (2016) Komunikasi verbal dan nonverbal. Jurnal Pendidikan \& Konseling 6 (2):83-98.

Lagu M (2016) Komunikasi antar budaya di kalangan mahasiswa etnik Papua dan etnik Manado di Universitas Sam Ratulangi Manado. Acta Diunar 5 (3):1-10.

Melamba B, Syukur L, \& Nggawu L (2015) The Lulo dance from traditional to MURI Record: Historical analysis of Tolakinese culture in Southeast Sulawesi, Indonesia. Tawarikh 7 (1):87-98. https://doi. org/10.2121/tawarikh.v7i1.625.

Moleong LJ (2010) Metodologi Penelitian Kualitatif. Bandung: Remaja Rosdakarya.

Mulyana D (2013) Metodologi Penelitian Kualitatif: Paradigma Baru Ilmu Komunikasi dan Ilmu Sosial Lainnya. Bandung: Remaja Rosdakarya.

Ngare F (2014) Studi komunikasi budaya tentang upacara ritual Congko Lokap dan komunikasi dalam pengembangan pariwisata daerah Manggarai Provinsi Nusa Tenggara Timur. JIKA 1 (1):40-50. https://doi.org/10.31294/kom.v1i1.230.

Putra YMP (2018) 11 warisan budaya Sultra masuk warisan nasional. [Accessed 3 April 2020]. https:// nasional.republika.co.id/berita/nasional/daerah/18/03/15/p5ms81284-11-warisan-budaya-sultramasuk-warisan-nasional.

Rahayuni R (2016) Pesan-pesan dakwah dalam film "Syurga Cinta". Thesis, UIN Sunan Kalijaga, Yogyakarta.

Rakhmat J (1996) Psikologi Komunikasi. Bandung: Remaja Rosdakarya. 
Saprillah (2016) Mengukur indeks kerukunan antar umat beragama di Kabupaten Konawe Selatan. Jurnal ‘Al-Qalam' 20 (2):269-280. https://doi.org/10.31969/alq.v20i2.196.

Sobur A (2013) Semiotika Komunikasi. Bandung: Remaja Rosdakarya.

Sulaeman, Kamaruzzaman, \& Malawat M (2019) The Ma'atenu communication rituals of Pelauw Muslims community. Jurnal Masyarakat, Kebudayaan dan Politik 32 (4):426-441. https://doi. org/10.20473/mkp.V32I42019.426-441.

Tamunu VR, Waani FJ, \& Tumengkol SM (2018) Analisis interaksionisme simbolik terhadap penyimpangan perilaku siswa (Kajian sosiologi pendidikan terhadap pelanggaran tata tertib siswa di SMA Negeri 9 Manado). Jurnal Holistik 11 (21):1-20.

Tarimana A (1993) Kebudayaan Tolaki. Jakarta: Balai Pustaka.

Walujo KW (2011) Wayang sebagai Media Komunikasi Tradisional dalam Diseminasi Informasi. Jakarta: Kementerian Komunikasi dan Informatika RI, Direktorat Jenderal Informasi dan Komunikasi Publik.

Wibowo ISW (2011) Semiotika Komunikasi: Aplikasi Praktis bagi Penelitian dan Skripsi Komunikasi. Jakarta: Mitra Wacana Media.

Wijaya HF \& Marta RF (2015) Mitologi budaya pada gelang dukacita sebagai atribut upacara kematian dalam tradisi Tionghoa Bangka dan Cina Benteng. Semiotika: Jurnal Komunikasi 9 (1):223-251. 